\title{
New Challenges in Corporate Governance: Linking M\&A and Social Responsibility
}

\author{
Tea Golja*, Morena Pauišić \\ Juraj Dobrila University of Pula, Croatia \\ *tgolja@unipu.hr
}

\begin{abstract}
Answers to the questions of successful business models can be found in various strategies, amongst which mergers and acquisitions are considered as good growth strategies if implemented successfully. Corporate governance is seen as control mechanism dependent on the legal, regulatory, institutional and ethical environment of the community. Thus, authors emphasize that without considering the social aspects of business, leaders cannot lead the business in the right direction, but vice versa. Mergers and acquisitions (M\&A's), as one option for the company's development could bring both positive, but as well as negative consequences for the target and the acquirer company. Corporate governance mechanisms, social responsibility and the importance of their adequate combination in the processes of merging and acquiring new company pervades in this paper. The paper brings insights on corporate social responsibility and the way its effective implementation supported by governance mechanisms can create a "snowball effect" of positive social changes. A special focus was put on M\&A and its incremental value for the company's development and growth. Important figures in the field of M\&A are provided. A deep theoretical background is provided in the field arisen out of detailed literature review and practical experiences.
\end{abstract}

Keywords: corporate social responsibility, corporate governance, mergers and acquisitions

\section{Introduction}

Global challenges and changes happening today, especially in this period of global economic and social turmoil, divert the business as usual model. A huge pressure has been put on businesses to integrate social and environmental issues into whatever they do. Only if companies rise to today's challenges, they will be in position to achieve the sustainable, balance growth, and thus directly contribute to the achievement of sustainable and balanced development. Corporate social responsibility is an opportunity to resolve real and challenging issues businesses have been facing today, even when selecting their growth strategies. It has been recognized as the proper model bringing many advantages to the businesses themselves (in terms of financial gains), to the local community where they operate, and after all to the global community. Good and effective, well designed corporate governance is a critical element for achieving excellence in terms of socially responsible business practice, as well as overall business success. When searching for new business models and new business strategies, different strategies should be taken into consideration. The growth strategy (i.e. mergers and acquisitions) is the one, which could bring benefits to the company. Authors find important to note that technological developments, primarily in the fields of computerization, communication and information, along with the process of globalization, processes of privatization of governmental companies, the liberalization in the transfer of merchandise and services between countries, and the trend of unification between fields and industries and companies and regions - all accelerate the popularity of the use of mergers and acquisitions (henceforth M\&As) strategy (Morag and Barakonyi, 2009). However, the strategy must be effectively implemented, meaning that corporate managers (top managers) must recognize the importance of socially responsible business practices. M\&As, as one option for the company's development could bring both positive, but as well as negative consequences for the target and the acquirer company. It all depends on the effectiveness of the process of integration. In the turbulent circumstances, it is essential to have good corporate governance sensitive to the sustainability issues able to assure success of the M\&A process. The aim of this paper is to provide an up-to-date overview of the concept of CSR, the benefits arising of socially responsible business practices and ways of its effective implementation through good corporate governance. Furthermore, a special focus was put on examining the links between the external corporate growth strategy (M\&A) and its effective implementation about the social responsibility and the role of corporate governance. 


\section{Literature Review}

In the text that follows, review of literature is provided, based on the focus of the paper-corporate governance, social responsibility and corporate activities in mergers and acquisitions.

Corporate Governance: Corporate governance is theme, which is in focus of the business world. Governance on top level is faced with challenging decision-making processes, timely actions, settings of corporate cultures and norms, stakeholders' expectation etc. The way in which affairs of corporate enterprises are governed is of considerable importance. One way of approaching the question of governance is to think in terms of how the interests of various stakeholders are balanced (Thompson, 1995). Corporate governance should be a control mechanism that ensures the optimum use of the human, physical and financial resources of an enterprise. The corporate governance framework (McRitchie, 1999) depends on the legal, regulatory, institutional and ethical environment of the community. From global perspective (Coombes \& Wong, 2004), six themes of importance are apparent : (1) rapid extension of governance codes worldwide; (2) increased focus on board professionalism; (3) selective redesign of corporate leadership roles; (4) re-assessment of corporate reporting needs; (5) more intensive external scrutiny of corporate governance and (6) increased attention to corporations' impact on society. From new perspective of corporate governance, all activities and pressures represent the fundamental challenge of coherently articulating and defining purpose of the corporation. This requires corporation's leaders to develop a carefully articulated set of core values and to ensure that these values are translated in entirely consistent ways, not just to investors, but to all the different constituencies with which a corporation deals (Coombes \& Wong, 2004) especially regarding legal norms and norms set by society. The good corporate governance is not a simple issue. Corporate governance is closely connected with managerial structures often in terms of power, responsibility, and duties as well as in establishing strategy to achieve main corporation goals. One of the most important goals of corporate governance is to maintain the confidence of stakeholders in corporation management / corporations. On other hand, to protect shareholders interests (profits). Today, new issues posed by globalization, lots of trust in business, civil society activism, and both legislated and voluntary movement lead toward corporate governance reform (Morgan, Ryu \& Mirvis, 2009). According to this, the Board's mandate is to ensure that controlling shareholders treat the firms other constituencies in a fair and non-preferential fashion. The decision making process, on corporate level, is not an easy task but nevertheless in order to contribute to the positive development of the company, decisions should be brought bearing in mind its consequences, thus highlighting the moral dimension of human beings (managers). Golja \& Paulišić (2010), it is to say that bringing decisions must involve moral perspectives of what possibly may decisions bring in the future (good or bad consequences).

Authors agree that corporate governance, being tightly linked with managerial structures must be based on moral foundations. Strategic management concepts allow an organization to initiate and influence its environment and thus control its own destiny (David, 1989). The current environment is grim, insecure and in this turmoil period, it is risky to involve company in growth strategies, but despite this hard time, corporate- level strategy should answer the question: How to manage a company's growth and development in order to maximize long-run profitability? The answer involves choices of both the business and the markets that the company is going to compete. Boards vary widely in the degree to which they are involved in strategic choices, but it is known well that board characteristics affect such fundamental choice as acquisitions, diversification, divestitures, research and development (Finkelstein \& Hambrick, 1996). One way to strengthen a company's position is to merge with or acquire weaker rivals to form the more competitive company and a larger share of the market. In that case, company decided to achieve comparative advantage through external growth strategies. Strategic managers need to be very sensitive to the problems involved in taking over new business through M\&As. Hill \& Jones (1992), External growth for governance on the corporate level brings uncertainties because of country- level governance standards in terms of secure property rights, an independent judiciary, reliable enforcement procedures and acceptance of the rule of law (Coombes \& Wong, 2004). In growth strategies, on international level, huge evaluation must be pointed on country's attractiveness, which is composed of its market size, the market rate of growth, the extent and type of government regulation, and economic and political factors. Other evaluation considers a products competitive strength, which is composed from its market share, product fit, contribution margin, and market support (Wheelen \& Hunger, 1992).

Corporate Social Responsibility: Each company, whether small, medium-sized or big, is able to contribute to the achievement of sustainable development by behaving responsibly. Social responsibility 
is important for all corporations operating in the society. Social responsibility begins where the law ends (Davis, 1973). The story of corporate social responsibility is very interesting. Although the formal writings on corporate social responsibility have been largely developed in the last 60 years (first in the USA, followed by Europe and Asia), corporate social responsibility has a pretty longer history. The acceptance of social responsibility changed from charitable giving to social responsiveness when corporations began to seriously take into consideration their influence on the society, and started to organize their systems of management in order to address more effectively CSR issues. The definition of CSR was different in different periods. In the early 1950s, very much concerned with CSR was Harold Bowen, so called "Father of Corporate Social responsibility" (Carroll, 2006). In his book Social Responsibility of Businessman (1953) he defines social responsibility as the obligation of businessman to pursue those policies, to make those decisions, or to follow those lines of action which are desirable in terms of objectives and values of our society The Philanthropic giving was always questionable as it was difficult to realize whether it was individual or business philanthropy. Nevertheless, different historical developmental periods have had strong influence on the development of corporate social responsibility. In some periods in the history it was marginalized, discredited, overlooked etc. What makes all this even more interesting is the point that today's' researchers, still do not have a precise and common definition of corporate social responsibility although it has been studied for so long. Could we say that this is a process, a theory, a part of management, a sort of political and social movement, or a field of scholarship as proposed by Lockett et al., (2006)? Hence, there is no common definition, but even further, there is no strong consensus that CSR is good for business, and whether corporations should engage in socially responsible activities. However, the today's crises in the confidence of business have shown that there has to be some corporate responsibility.

There have been several different approaches to CSR. Bearing in mind the point that CSR deeply enters into the different segments of social reality - economics, politics, social integration and ethics, Mele (2008) distinguishes four CSR theories that emphasize different responsibilities business has towards the society, and thus the models, which find themselves within different theories, vary between themselves in defining CSR. These theories are:

- Corporate social performance,

- Shareholder value theory or Fiduciary Capitalism or Agency Theory,

- Stakeholder Theory and

- Corporate Citizenship.

The basic framework of the first theory (Corporate Social Performance theory) underlines the point that business operates in the society, which legitimizes its activities and provides the main resources for conducting different business activities. Business has power and power requires responsibility. Thus, business requires taking greater responsibility towards the society. In this context, two models that possibly provide the best way to define, interpret and provide deeper understanding of this theories are the definition of CSR provided by Carroll (1979), most popularly known as the Carroll's pyramid of responsibilities which was later revised and the alternative was provided by Schwartz and Carroll (2003) and the second model is the Wood's model which might be considered as the most representative in explaining CSR. Carroll (1991) defined corporate social responsibility as the one, which encompasses economic, legal, ethical and discretionary expectations that society has of organisations at a given point of time. Thus, corporate social responsibility calls companies to strive for balance between (1) the economic responsibility to reward shareholders with profits, (2) the legal responsibility to comply with laws of the countries where it operates, (3) the ethical responsibility to abide by society's norms or what is moral and just, and (4) the discretionary philanthropic responsibility to contribute to non-economic needs of society (Carroll, 1979). Later this approach was a little bit changed due to the discretionary elements of philanthropic category, and Schwartz and Carroll (2003) proposed a Venn model framework encompassing economic (to be economically sustainable), legal (to stay within the law) and ethical business responsibilities (to do what is just and right to do). Wood (1991) expresses principles of CSR on three levels - institutional (Principle of Legitimacy), organizational (Principle of Public responsibility) and individual (Principle of Managerial Discretion) principle. Shareholder Value Theory underlines that the only responsibility of business is to make as much profits as possible. This goes in line with "meet and beat the numbers" notion. This is a Principal- Agent view where shareholders are the principals and managers are their agents.

At this point it could be considered important to mention that managers, in order to get the share prices as high as possible, or the market value of the share as better as possible, managers could take different 
activities such as merging their company to another one or could engage in the process of acquiring another company. These processes could be considered very insecure as they could cause economic instability. Corporation itself could not be held responsible for any of its activities, but managers and executives should. Corporation is an institution and has no conscious, nor responsibility. Managers are those who have conscious and whose activities are to be judged as good or bad, ethical or not etc. This goes very much in line with what Friedman (1970) said that "there is one and only one social responsibility of business--to use its resources and engage in activities designed to increase its profits so long as it stays within the rules of the game, which is to say, engages in open and free competition without deception or fraud." The accent here was put on the engagement in open and free competition without deception and fraud and thus, this could be interpreted as staying within the ethical standards of the culture where the company operates, complying with the law of the country and depending on managers' moral values. Stakeholder theory takes into account different stakeholders - both those who have more and less interest in the corporation. Freeman was the greatest proponent of this theory. He sees the main purpose of the firm as the one serving as the vehicle for coordinating stakeholders interests. Ewan \& Freeman (1988), basically, managers should in order to benefit different stakeholders, bring decisions and engage in activities with respect to shareholders, employees, customers, suppliers, local community, financial analysts, NGOs and other stakeholders under direct or indirect influence of the particular corporation. Ewan and Freeman base the legitimacy of Stakeholder theory on two ethical principles: Principle of Corporate Rights according to which the corporation should not violate the legitimate rights of others to determine its future and Principle of Corporate Effects according to which the corporation and its managers are responsible for the consequences of their decisions (Melè, 2008). The globalisation process has had enormous influence on the way business is done. Globalisation has enabled corporations to expand their business worldwide, as well as to allocate their production chain in different countries throughout the world mainly bearing in mind costs of production, thus allocating production factories in less developed countries. All this contributed too many immoral activities in the last decade.

On the other side, although business corporations have been left on their own to bring decisions in a way to provide maximum benefits for their shareholders, many anti-globalists movements and greater customer awareness have put a caution on the way business has been done - not only locally but more globally. Corporate citizenship theories and approaches are focused on rights and duties, responsibilities and possible partnerships of business with societal groups and institutions (Melè, 2008). Hence, corporate citizenship focuses on the corporation's behaviour in the global context, in the global arena, thus focusing on many other global stakeholders and respecting universal human rights. Takala's (2000) distinguishes three models of business:

- Owner oriented,

- Stakeholder oriented and

- Wide responsibility oriented.

It is easy to note how different theoretical contributions can easily fit in some of the above-mentioned categories. Thus, shareholder approach to business falls into the first, stakeholder approach into the second and corporate citizenship and corporate social performance into the third category or third category of so-called "business in the society model". Galbreath (2006) distinguishes four different strategic options, which are also, very much connected to all the above mentioned: the shareholder strategy (focus on maximization of shareholder returns), the altruistic strategy (focus merely on philanthropy), the reciprocal strategy (focus on creating partnership with the society) and the citizenship strategy (focus on finding optimal balance between different stakeholders in the global community). The term corporate governance, corporate responsiveness, triple bottom line (proposed by Elinghton in 1998), responsible behaviour or corporate social responsibility have been much in use recently and very challenging is their interchangeable use. There is still no consensus made upon which one describes better the relationship between the corporation and the society. Namely, they are all-good and show different perspectives, and everything depends on as Melè (2008) emphasized - what are you looking for? All the above-mentioned theories provide somehow different context of CSR and different vision, thus providing different definitions. Corporate social responsibility is the micro aspect of sustainable development. There are many definitions of corporate social responsibility, and many different aspects covered by different definitions, but most important point is that all of the definitions cover three most prominent areas of corporate social responsibility - economic responsibility, environmental responsibility and societal responsibility. This is why the underlying triple bottom line approach developed by Elkington (1998) has been widely accepted. It means that the company should be able to improve the capacity of the society to fulfil its aspirations, whilst improving the economic well-being and 
the quality of life of the community in which it operates, at the same time should take care of the environment and focus on improving its conditions.

When focusing on the triple bottom line - company's environmental, social and economic aspects, sometimes, focusing on the financial aspect might be a bit confusing. Financial aspect does not only consider revenues, losses and profits, but also the other side, which is often left with little or no attention at all. This other side includes creation of jobs, generation of income, wages, investment in human capital, goods bought and sold, taxes paid to the local community, region or state taxes which contribute to the overall development of the community and hence, region and state. Specially, if we turn to the global economic turndown happening in the world today, this aspect of the triple bottom line should definitely be put on the top of the companies' priorities. Herewith, we are providing some recent definitions of CSR, which are somehow different, because of different approaches and theories they have flourished from, but they could be considered appropriate for the context needed. Corporate Social Responsibility is a concept whereby companies integrate social and environmental concerns in their business operations and in their interaction with their stakeholders on a voluntary basis. (Communication from the Commission to the European Parliament, The Council and the European Economic and Social Committee, 2006) Here we have to point to the fact that behaving responsibly is a voluntary decision made by each company, not an obligation and it is better if not imposed, but simply still beyond law because it enables companies to compete and engage in more and more activities, but does not constrain them into something specifically. Corporate social responsibility defines organizational consideration of multiple stakeholders and global impact, beyond simple focus on maximization of shareholder wealth. Corporate social responsibility as a term may be solely perceived as strictly oriented towards and for big companies, but bearing in mind that in the majority of countries around the world small and medium sized enterprises constitute a vital part of the economy, contribute to the creation of employment, GDP growth, and value added, they should not be considered less responsible than large companies. This is why they should also integrate social and environmental issues into their ordinary business practice. For companies to behave responsibly it is of crucial importance to start to behave as good corporate citizens.

CSR brings many advantages to companies that decide to operate responsibly. In order to conduct business in a responsible way, companies should combine very many different activities with respect to their main stakeholders and the community they operate in, and for competitors it will be more difficult to imitate the whole spectrum of activities than only one particular (Porter, 1999). Thus, company can gain competitive advantage in implementing socially responsible business decisions. Regarding the financial performance, it is important to note that the majority of the researches, which were analyzing corporate financial and social performance, have resulted in finding the positive relationship between corporate social and corporate financial performance (Margolis \& Walsh, 2003). Other benefits arising from socially responsible practices include attracting and retaining the best employees, customer loyalty, good reputation and brand value and others. However, Kurucz, Colbert \& Wheeler (2008) pointed out four general types of business case for CSR based on existing reviews and models of CSR. These are:

- Cost and risk reduction $\rightarrow$ the firm will choose whether to engage or not in different CSR, activities depending on costs and risks connected with them.

- Competitive advantage $\rightarrow$ supply and demand theory, base of the pyramid approach, a natural resources-based view

- Reputation and legitimacy: building a responsible brand $\rightarrow$ licence to operate, social impact hypothesis, cause-related marketing, socially responsible investment

- Synergic value creation $\rightarrow$ combination of slack resources and good management, sustainable local enterprise network, societal learning.

Connected with this, Kurucz, Colbert \& Wheeler (2008) emphasized the four business cases for CSR with regards to the eras of CSR (developmental eras of CSR, as already mentioned), thus presenting the four models of value creation in the CSR business case. This is presented in the Scheme 1.

From the below picture it is notable that the evolution of social systems, culture and worldview in terms of pre-conventional, conventional and post-conventional states can be linked with different eras of CSR (shareholder primacy, stakeholder primacy and social integration) as well as with the definitional locus of CSR. In the first era of CSR, the only purpose of business is to make profits and the focus is put on shareholders. Thus, the cost and risk reduction and partly the competitive advantage approach can be linked with this era. In the second era, the main locus shifts on to the different stakeholders and not only shareholders. In this era, the corporation is adapting its business operations to the society where it operates, bearing in mind different stakeholders around itself. Competitive advantage as well as 
reputation and legitimacy approaches are linked with this era of CSR. A third era or a societal approach builds on the perspectives of the previous eras, but most of the entire corporation is adapting its business operation to the societal commons and business is seen as an economic, political and social actor. The synergistic value creation begins to advance into this era. Corporate governance is considered as critical element for driving excellence in corporate social responsibility (Shahin \& Zairi, 2007).

\section{Scheme 1: Four models of value creation in the CSR business case}

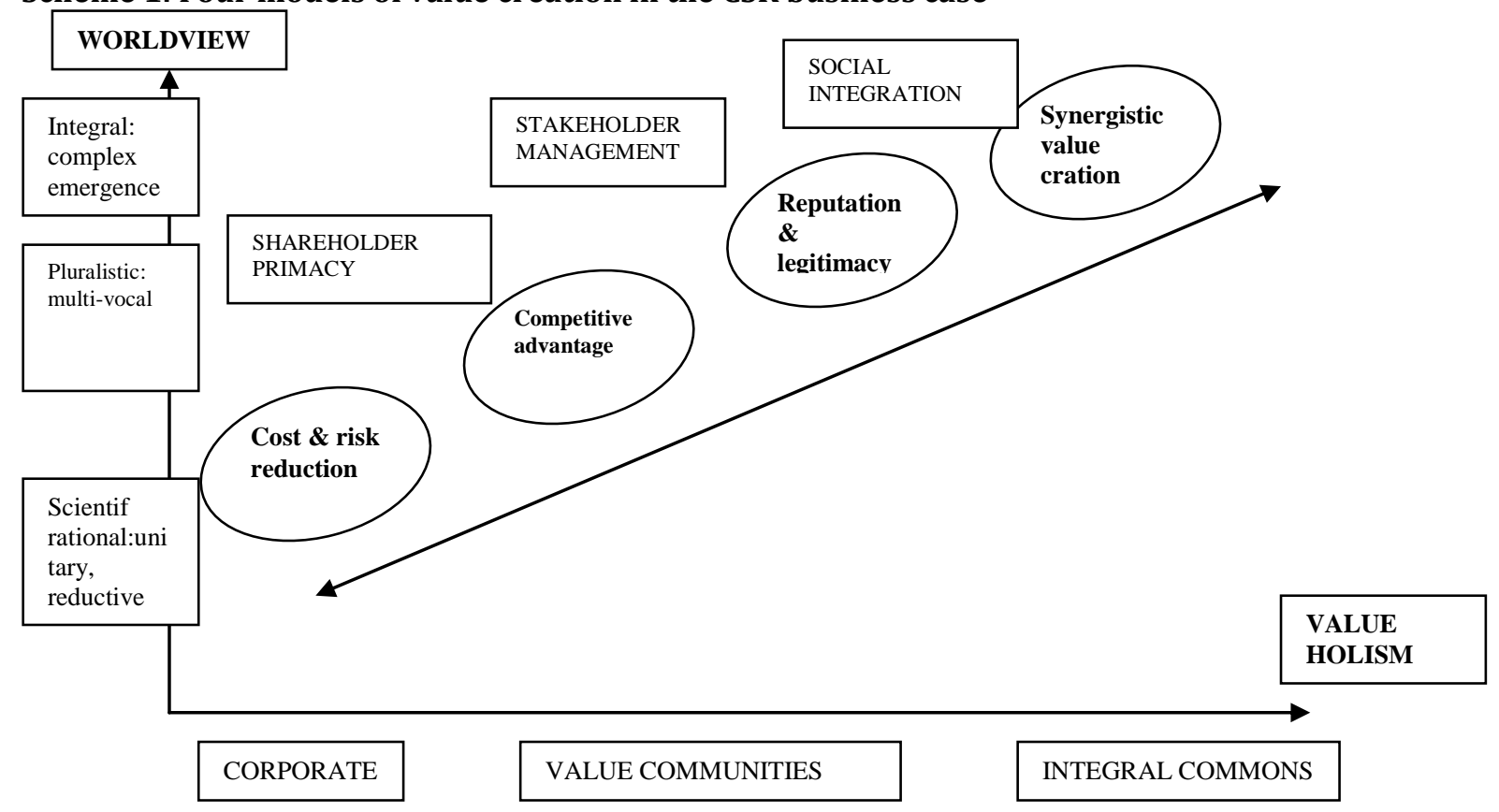

Source: Kurucz, Colbert \& Wheeler (2008)

\section{Mergers and Acquisitions}

Companies search incessantly for new business models and business strategies that will improve qualities, as fast as possible, so that they can respond in the best possible way to the changing demand of the clients and to the changes in the map of competition in the domain (Morag \& Barakonyi, 2009). When corporate governance considers types of strategies appropriate for company - one option is the growth strategy. After choosing growth strategy, it must be implemented. The options are: (1) M\&As; (2) internal development; (3) strategic partnering. Some of the firms lack time, management expertise, and operations knowledge to take advantage of environmental opportunities for growth by engaging in internal innovation and development. So, the acquisition of, or merger with another organization produces a rapid or incremental growth in revenue, profits, assets, etc. (Montanari, Morgan \& Bracker, 1990). In external growth, the company is aided by the resources and abilities of other companies and this synergy can significantly improve the company's competitive ability. Thus, the strategy of M\&As is one of the main strategies adopted by companies and corporations so as to expand into new markets, diversify products and services, and increase the competition in the field (Morag \& Barakonyi, 2009) Growth through M\&A include (Montanari, Morgan \& Bracker, 1990):

- Vertical integration - growing through greater ownership of sources of input or channels of distributions;

- Horizontal integration - acquisition or merger with competitors;

- Horizontal diversification - acquisition of new products lines for existing customers;

- $\quad$ Concentric diversification - acquiring new but related product lines for new customers;

- $\quad$ Conglomerate diversification - acquiring new and unrelated product lines for new customers.

There are lots of theoretical contributions to the field of M\&As. Formerly, the term „merger" applied to the consolidation of two companies about equal in size, where an „acquisition“ involved a larger firm taking over a smaller one. However, this distinction in practice was not significant on country- level 
governance (Newman \& Logan, 1971). For Bartol \& Martin (1991) an acquisition is the purchase of all or part of an organization by another; while a merger is the combining of two or more companies into one organization. According to Wheelen \& Hunger (1992), a merger is a transaction involving two or more corporations in which stock is exchanged, but from which only one corporation survives. Mergers usually occur between firms of somewhat similar size and are usually "friendly". The resulting firm is likely to have a name derived from its composite firms. An acquisition is the purchase of a corporation that is completely absorbed as an operating subsidiary or division of acquiring corporation. Acquisitions often occur between firms of different sizes and can be either friendly or hostile. Almaney (1995) supports the above-mentioned definition, with the difference that the absorbed corporation from his point of view becomes a strategic business unit (SBU) with identifiable group of employees, customers, suppliers etc. Coulter (1998) explained that "mergers" and "acquisitions" are not synonyms, but are both describing situations in which an organization combines its operations with another, but each involves a different approach. A merger is a legal transaction in which two or more organizations combine operations through an exchange of stock, but only one organization entity will actually remain. Mergers usually take place between organizations that are similar in size, and are usually "friendly"- that is a merger is usually acceptable to all the concerned parties. An acquisition is an outright purchase of an organization by another. The purchased organization is completely absorbed by the purchasing organization. Acquisitions usually are between organizations of unequal sizes and can be friendly or hostile. In a hostile acquisition, called a takeover, the organization being acquired, does not want to be acquired.

Kim, Nofsinger \& Mohr (2010) gave the explanation started from generally view that M\&As as being somewhat different (a merger - is often viewed as a combination of two firms, whereas an acquisition- is viewed as one firm buying another), almost all mergers are essentially acquisitions, as there is often an explicit buyer and seller where two firms are joined together. In addition, some believe that managers want to take over companies simply to increase their "empire", and this kind of acquisition is often referred to as "empire building" (Kim, Nofsinger \& Mohr, 2010). In process of integration, the firm that is buying is called acquirer and the firm that is being sold is called the target (Kim, Nofsinger \& Mohr, 2011). In principle, the decision to merge with or acquire another firm is a capital budgeting decision much like any other. However, M\&As differ from ordinary investment because of its value; the accounting, tax, and legal aspects which can be complex. M\&A often involve issues of corporate control and replacing existing management, affect the value of the firm, and finally, are hard to accept especially for employers, managers of acquiring firm, community and other stakeholders. The Boston Consulting Group (2009) suggested matrix to clarify a company's M\&A strategy depends on two factors: (1) operational stability and (2) financial stability, which results with four (4) types of company: Prey, Predators, Liquidators and Cyclical leaders. (Table 1)

Table 1: BCG Predator - Prey Matrix

PREY
preserve intrinsic value of businesses
pay down debt
sell non-strategic businesses to pay off debt
restructure debt schedule to reduce risk
default

\section{LIQUIDATORS}

sell off assets to reduce debt

improve profitability of remaining

businesses

liquidate if unable to improve profitability above cost of capital

\author{
PREDATORS \\ enhance competitive advantages \\ gain market share profitably \\ invest wisely where returns are above cost of equity \\ acquire prey when long-term value can be added \\ acquire good pieces of business that is, products \\ that fit) and avoid toxic portions of liquidators
}

\section{CYCLICAL LEADERS}

improve near-term EBIT as quickly as possible; reduce operational volatility in order to become less vulnerable in future downturns

avoid excessive debt that would turn the company into a liquidator

Source: BCG (2009): Be Dearing while others are Fearful, www.bcg.com (25.6.2010.)

Most desirable companies are Predators, they have high operational stability and high financial stability and they are interested in M\&A activities to enhance competitive advantages, they are desirable for stakeholders, they can gave new support to community etc. On other side, Liquidators with low operational stability and low financial stability are not desirable strategic options for corporations and community. M\&As can occur for reasons other than business difficulties, such as the desire to move into new markets, expand existing markets, boots technological expertise, to reduce competition by absorbing 
an important competitor organization; to manage interdependence with either sources of input or purchasers of output by absorbing them or to diversify operations and thereby lessen dependence on the present organizations with which it exchanges, penetrating new geography regions etc. (Bartol \& Martin, 1991, Quin, Mintzberg \& James 1988). M\&As are performed in the hopes of realizing an economic gain. In addition to antitrust hurdles, every merger directed toward productivity gains involves financial negotiations, revamping organizations, career readjustments, perhaps physical moves, and other changes. A manager could avoid these burdens by expanding from within instead of merging with a stranger. Clearly, a merger must offer strong advantages over internal expansion. A sound merger must provide major benefits in terms of time, expense, or physical possibility. (Newman \& Logan, 1971, pp. 326) M\&A is closely connected with corporate governance especially in case when firm is poorly managed; one way to force management and the board to make changes is to buy all of the shares of stock in the company and then use the voting power of this stock to replace the board and management (Kim, Nofsinger \& Mohr, 2010).

The possible motives for M\&A are varied. Thus, European Commission (2009) underlines:

- A search for efficiency gains through new combinations of material and immaterial assets,

- A drive to increase market shares and market power,

- A desire to safeguard access to important inputs,

- A search for access to new technologies and know-how,

- A drive to gain access to new customer groups or new geographic markets,

- A desire for diversification.

M\&As often result in a number of social benefits. Mergers can bring better management or technical skill to bear on underused assets. Mergers can also produce economies of scale and scope that reduce costs, improve quality, and increase output, insure new employment, founding new community projects, etc.

M\&As merit special attention, especially with regards to European Union, whether one is the in position of consumers, entrepreneurs, academics, regulators or policymakers. Not everyone will benefit from mergers and acquisitions. The pooling of assets through M\&A can lead to efficiency gains, with benefits to consumers if the gains are passed on in the form of lower prices, higher quality or new products and services. (European Commission, 2009) However, if M\&As are not controlled by an effective competition policy they may lead to excessive market concentration and anti-competitive behaviour, so that consumers find themselves paying higher prices or faced with poorer quality goods and services. Numerous empirical researches attempted to identify external variables (related to the field and the environment) and internal variables (related to the companies involved in the process) that will help predict the success of the M\&As. The impact of variables such as previous experience in acquisition, mode of payment for the acquisition, level of relatedness between the companies, and the type of acquired company, variables that seem to greatly influence the acquisition success, are examined, a significant correlation has not been identified between them and the M\&A success (Morag \& Barakonyi, 2009). When asked to pinpoint the critical elements of a successful cross-border M\&A transaction, managers often cited "orchestrating and executing the integration process" (47\% of respondents), conducting due diligence (43\%), and energizing the organization and understanding cultural issues (40\%). Interestingly, the same factors were generally seen as key to successful domestic transactions, though cross-border deals obviously place greater emphasis on culture differences and various integration approaches (Morag \& Barakonyi, 2009).

In valuing the business being traded, agreement must be reached on what is to be traded and the value to be attached to it. What is included, basis of evaluation - especially to the owner of a family business. Men who have devoted their lives to building an enterprise normally have deep concern about perpetuating the company name and reputation; their interest is in the future welfare of their employees; they want the company to continue to give support to the community in which they live. In addition, in selling the company, these men may be sacrificing an attractive salary and a prestigious position (Newman \& Logan, 1971). The process of re-organization of the combining companies is a critical process that should be accomplished early, quickly, and correctly, so Smith (2007) suggested these guidelines:

- Specify the objectives.

- Specify the benefits for the stockholders of both firms

- Ensure that the managers of the acquired firm are competent or can be made competent.

- Ensure that the resources of the two firms are compatible and offer synergistic possibilities.

- Involve both CEOs in the entire merger process. 
- Cleary define the business or purpose of the acquiring firm.

- Examine the strengths, weaknesses, and other performance factors of both firms.

- Create a climate of trust between the organizations by anticipating a merger and dealing with it early and openly.

- Make the right advances, and make them smoothly and tactfully.

- Exercise a minimum control over the new firm and maintain or improve the status of the newly acquired managers.

However, many M\&As in practice fail. M\&A (Montanari, Morgan \& Bracker 1990, Tushman \& Anderson, 1997) incorporate several risks - the cost of acquisition, not compatible corporate culture, causing an exodus of management personnel, the financial and managerial demands of the new acquisition, liability to overlook many subtle details while screening candidates, move focus from products, control system, financial results, growth size to new activity. M\&As carry risk for all stakeholders. Despite of popularity these activities often do not bring the gains predicted, so McKinsey \& Company tried to give an answer on question: Why so many acquisitions fail: (Hill \& Jones, 1992)

- companies often experience difficulties when trying to integrate divergent corporate cultures;

- companies overestimate the potential gains from synergy;

- $\quad$ acquisition tend to be very expensive;

- companies often do not adequately screen their acquisition targets.

Newman \& Logan (1971) explained that some of these failures are due to poorly conceived combinations - the marriages of convenience that never were thought through. Others are high-risk ventures that turn up in the losing column. Rarely can managerial skill save such ill-fated mergers. Palmer (2005) offered an approach, that most executives manage the business integration but do not manage the human integration. Eager for the gains anticipated, they treat the acquisition like a series of financial reports, instead of proud and vibrant organizations comprised of human beings. First, the people who focus on the acquisition are skilled in strategy, the industry and in finance. They have a very clear picture of the desired objectives of the acquisition, and understand how the new organization should return business efficiencies. However, given the time demands of the pre-purchase activities, and their tendencies to focus on financial and business issues, the "people" issues often receive short shrift. Second, the people most affected by the action-the employees of the purchased organization-do not know the business objectives, see change as a threat, have no real influence over the events, and wonder immediately how they will be affected personally.

Actions taken immediately after contracts have been signed as critical to the success of a merger. Too often, a manager who prepared the M\&As move on the new positions or tasks, and consequently the synergistic potential of the merger is only partially realized. The goal of post-merger integration should be value creation, not just quick integration, and that post-merger activities should be prioritized according to the value they are believed to create. A variety of considerations enter into a good merger. The Boston Consulting Group (2009) suggested that post-merger integration must be rigorous, with cash generation the top priority. The strategic and tactical choices made before a deal is closed ultimately determinate its success- and never more so than in a downturn. What is seen from the theory of postmerger integration is that companies are not focused on "people" and that culture, communication, teamwork; trusts are not in the focus of corporate governance, what should be changed in future. Since mergers and acquisitions are so complex, however, it can is very difficult to evaluate the transaction, define the associated costs and benefits, and handle the post-merger integration. The quantity of M\&As in the world has been constantly rising the popularity of this strategy from the 1980 s. Investment in M\&A activity was steadily increasing from 2000 till the recession in 2007. This is presented in the Figure 1.

\section{Figure 1: Share of global M\&A by geography of target, in percentage}

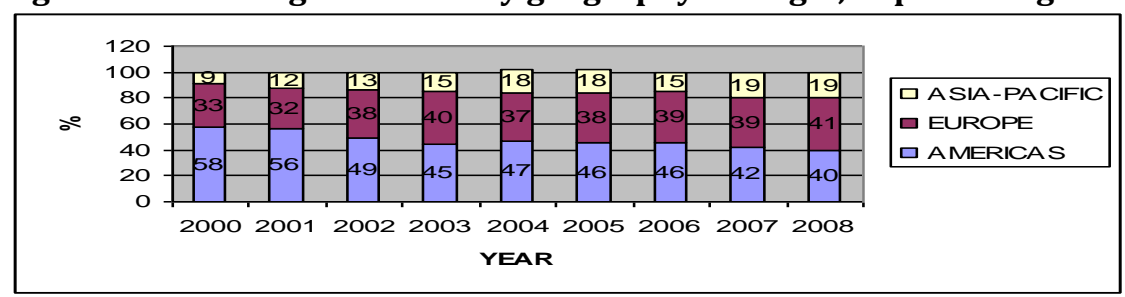

Source:http://www.tricappartners.com/images/McKinsey_Jan_2009__What_s_Different_About_M_A_in_This_Downturn.pdf 
In terms of US dollars, the total amount has been slightly falling in the first three years; from 3.3 trillions of USD in 2000. To 1.7 trillion USD in 2001. In addition, 1.3 trillion USD in 2002, followed by a slow increase with reaching of the highest level in 2007 or 4.6 trillion USD. In 2009 mergers and acquisition have been slowed down with many companies either unable to get the credit that they need to make acquisitions or too uncertain about the future to make a move. The financial crises have strongly affected M\&A markets loosing M\&A activities. There has been a huge decrease $(25 \%)$ in M\&A activities ever since 2008 (Lehman bankruptcy). The most visible and most controversial element in emerging multinationals' expansion is corporate acquisition, seen by many directors as the fastest way to advance. Current situation best describes recent integration. In Europe, Geely, the Chinese carmaker, is finalizing a $\$ 1.8 \mathrm{bn}$ ( $€ 1.4 \mathrm{bn}$ ) acquisition of Volvo, the Swedish manufacturer. Li Shufu, Geely's poetry-writing founder, says the Volvo takeover is the perfect antidote for what his own and most other Chinese carmakers lack: technology, research capability and a reputation for quality and dependability. In Africa, India's Bharti Airtel is set to become the world's fifth-largest mobile phone operator through the $\$ 10.7 \mathrm{bn}$ purchase of the regional assets of Zain, the Kuwaiti telecommunications group. In the US, Reliance Industries, India's biggest private sector company, is completing a $\$ 1.7 \mathrm{bn}$ joint venture with Atlas Energy after narrowly failing in Europe with a \$14.5bn bid for Lyondell Basell, a Dutch chemicals group (Wagstyl, 2010). The biggest cross-border acquisition this year (2010) so far is the planned $\$ 35.5 \mathrm{bn}$ purchase by British insurer Prudential of AIA, the Asian business of US group AIG - a more conventional case of a developed world company moving into emerging markets. However, in corporate acquisitions, we can noticetakeovers by emerging world companies of developed world groups. On the other side, it is very interesting to note the possible change in this trend. Rodolfo De Benedetti of CIR, an Italian conglomerate said "In the next few years we will see a growing number of acquisitions in Europe and the United States by companies based in emerging markets, especially in Asia and South America, these companies today have considerable financial resources and good management, and are interested in entering new markets and acquiring competitors." (Wagstyl, 2010) That is reality, which on best way describes the future.

\section{Final Remarks and Discussion}

The world we live is rapidly changing. Business plays a decisive role when focusing on the achievement of sustainable development. Personal and ethical values are becoming strong motivators for a business to start with supporting and respecting social and environmental concerns. If companies are to gain profits, they should be aware that the global changes are taking different route - the one towards sustainable development. The nature is providing us all of the resources we use and need for our normal life. If we are to destroy it, we are destroying ourselves primarily. This is why we need to protect the environment. Besides protecting the environment, we have to protect the society. The lifestyle patterns should be changed. What is expected of business is to implement socially responsible practices in their ordinary business activities. In this paper, authors discussed about the importance of socially responsible activities supported by transparent governance system help the business to grow sustainably, even when deciding to choose the external growth strategy. The best way to efficiently implement socially and environmentally desirable business activities is only possible through well-structured corporate governance system. Corporate governance is part of management; it depends on managers and strategic plans of corporation. It relies on internal (employees, knowledge, strategy) and external (law, institutions, markets) factors, both important in order to achieve incremental business opportunities, especially with regards to business development in the future. M\&As, as external company's growth possibilities are considered good business models if the integration is successful, but all this is very much dependent on good corporate governance, apart from being extremely dependent on external (environment) and internal (companies involved in the process) variables as well. Good corporate governance is taking into consideration new issues brought by globalization process when bringing decisions and implementing different systems (i.e. environmental, quality, safety and security, developmental issues etc.). This is due to huge pressures from different stakeholders (local and regional community, government, NGOs, consumers, suppliers, trade unions, financial analysts etc.) and their greater awareness and possibilities to express their opinion. Thus, respecting human rights, fostering gender equality and protecting the environment comes on the top of priority agenda for the business people.

When considering the possibility to merge with or acquire another company, without bearing in mind all the sensitive social issues, the attempts may result in failure to integrate properly and efficiently. Obviously, there must be a rationale for the M\&A activity. The acquirer should believe that the acquisition of the target company is aligned with its strategy and has excellent commercial rationale; it is enforcing existing positions, offering products or services to similar customers, and increases exposure to new 
markets. The advantages of this transaction include provision of numerous synergies across the two businesses. However, everything must be backed by strong moral and socially committed actions and supported by strong and transparent governance mechanisms. As emphasized in the paper, many M\&As do not succeed in the practice. Many of them bring negative consequences. Thus, authors share the view that the commitment of top managers to sensitive social issues should be prioritized in front of financial gains achieved when implementing this kind of growth strategy. If the board is not dedicated to commit these view changes and to foster the importance of social policy throughout the company (especially in post-merger activities), the success is very limited and questionable. The paper's aim was to shed some light on the importance of integrating socially responsible activities through corporate governance especially when focusing on growth strategies. The crises we have been facing today revealed many serious issues. Majority of them highlight the lack of social dimensions when doing the business. Thus, authors concluded with the point that corporate social responsibility is a concept, which can transform the ordinary into successful business, but only if recognized in the corporate governance system. Otherwise, the issues may become even more severe. Deep literature review helped to achieve the aim. However, it was combined with providing practical insights, as well as new figures showing current situation in the field of M\&As.

\section{References}

Almaney, A. J. (1995). Strategic management - the process of gaining a competitive advantage. Illinois: Stipes publishing L.L.C.

Ambrien, A. (2010). Scope of Mergers and Acquisitions. http://www.articlesnatch.com/Article/ScopeOf-Mergers-And-Acquisitions-/1124529.

Bartol, K. M. \& Martin, C. D. (1991). Management, New York: McGraw-Hill Inc.

BCG. (2009). Be Dearing while others are Fearful. Seizing M\&A Opportunities While They Last, www.bcg.com

Bowen, H. (1953). Social Responsibility of the Businessman, New York: Harper \& Row.

Byars, L. L. (1991). Strategic management: Formulation and Implementation, Concepts and Cases (3 $3^{\text {rd }}$ ed), New York: HarperCollins Publishers Inc.

Carroll, A. B. (1979). A Three Dimensional Conceptual Model of Corporate Performance. Academy of Management Review, 4(4), 497-505.

Carroll, A. B. (1991). The Pyramid of Corporate Social Responsibility: Toward the Moral Management of Organizational Stakeholders. Business Horizons, 34(4), 39-48.

Carroll, A. (2006). Corporate Social Responsibility: A Historical Perspective, in Marc J. Epstein and Kirk O. Hanson (ed), The Accountable Corporation 3, Westport, Conn.: Praeger Publishers, 3-30.

Certo, S. C. \& Peter, J. P. (1995). The Strategic Management Process (3 $3^{\text {rd }}$ ed), USA: Richard D. Irwin Inc.

Coombes, P. \& Wong, S. C. Y. (2004). Why Codes of Governance Work. McKinsey Quarterly, 2, available at: http://www.mckinseyquarterly.com/Why_codes_of_governance_work_1416

Coulter, M. K. (1998). Strategic Management in Action, New Jersey: Prentice-Hall Inc.

David, F. R. (1989). Strategic management ( $2^{\text {nd }}$ ed), Ohio: Merill Publishing Company.

Davis, K. (1973.) The Case For and Against Business Assumption of Social Responsibilities. Academy of Management Journal, 16, 312-22.

Elinghton, J. (1998). Cannibals with Forks: Triple Bottom Line of 21st Century Business, Gabriola Island, Canada: New Society Publishers.

Ewan, W. M. \& Freeman, R. E. (1988). A Stakeholder Theory of the Modern Corporation. Kantian Capitalism in Crane et.al. (2008). The Oxford Handbook of Corporate Social Responsibility, New York: Oxford University Press, 47-82.

Finkelstein, S. \& D. C. Hambrick. (1996). Strategic leadership: Top executives and their effects on organizations.New York: West Publishing Company.

Friedman, M. (1970). The Social Responsibility of Business is to Increase its Profits. The New York Times Magazine, 13, 1-6.

Galbreath, J. (2006). Corporate social responsibility strategy: strategic options, global considerations. Corporate Governance, 6(2), 175-187.

Golja, T. \& Paulišić, M. (2010) Corporate Governance, social responsibility and corporate reputation: an empirical analysis of the situation in Croatia. International Journal of Economic Policy in Emerging Economies, 3(4), 368-383.

Hill, C. W. L. \& Jones, G. R. (1992). Strategic management an integrated approach (2 ${ }^{\text {nd }}$ ed), Boston: Houghton Mifflin Company.

Josephson, M. (1996). Making Ethical Decisions (4th ed), Marina del Rey, CA: Josephson Institute of Ethics. 
Josephson, M. (2002). Making ethical decisions. Marina del Rey, CA: Josephson Institute of Ethics.

Kim, K. A., Nofsinger, J. R. \& Mohr, D. J. (2010). Corporate governance (3 ${ }^{\text {rd }}$ ed), New Jersey: Pearson Education Inc. Prentice Hall.

Kurucz, E. C., Colbert, B. A. \& Wheeler, D. (2008). The Business case for Corporate Social Responsibility in: Crane et al., The Oxford Handbook of Corporate Social Responsibility, New York: Oxford University Press, 83-112.

Lockett, A., Moon, J. \& Visser, W. (2006). Corporate Social Responsibility in Management Research: Focus, Nature, Salience and Sources of Influence. Journal of Management Studies, 43(1), 115-36.

Logsdon, J. \& Wood, D. J. (2002). Business citizenship: From domestic to global level of analysis. Business Ethics Quarterly, 12, 155-188.

Margolis, J. \& Walsh J. P. (2003). Misery Loves Companies: Rethinking Social Initiatives by Business. Johnson Graduate School: Cornell University

McRitchie, J. (1999). Blogs On Corporate Governance, retrieved from: http://corpgov.proxyexchange.org/

Melè, D. (2008). Corporate Social Responsibility Theories in: Crane et.al. (2008). The Oxford Handbook of Corporate Social Responsibility. New York: Oxford University Press, 47-82.

Montanari, J. R., Morgan C. P. \& Bracker J. S. (1990). Strategic management a choice approach, Orlando: The Dryden Press.

Morag, O. \& Barakonyi, K. (2009). The Influence of Speed of Integration on M\&A Integration Success. Budapest Management Journal, 40, 55-59.

Murphy, P. E. (1978). An Evolution: Corporate Social Responsiveness. University of Michigan Business Review, 4, 20-22.

Newman, W. H. \& Logan J. P. (1971). Strategy, Policy, and Central Management, Ohio: South-Western Publishing Co.

Palmer, B. (2005). Why 70\% of Mergers and Acquisitions Fail, and why this doesn't have to happen to You, http://www.interlinkbusiness.com/artmergers.html

Porter, M. E. (1999). Creating advantage. Executive Excellence, 16(11), 13-14.

Quinn, J. B., Mintzberg, H. \& James, R. M. (1988). The strategy process- concepts, contexts, \& cases, New Jersey: Prentice Hall.

Schwartz, M. S. \& Carroll, A. B. (2003). Corporate Social Responsibility: A Three-Domain Approach. Business Ethics Quarterly, 3, 503-30.

Shahin, A. \& Zairi, M. (2007). Corporate governance as a critical element for driving excellence in corporate social responsibility. International Journal of Quality and Reliability Management, 24 (7), 753-770.

Smith, A. D. (2007). Making the case for the competitive advantage of corporate responsibility. Business Strategy Series, 8, 186-195.

Takala, T. (2000). Nykyajan yrityskansalaisuus (Current corporate citizenship. In Yrityksen vastuut (Responsibilities of a Company), Taloudellinen Tiedotustoimisto (Economic International Bureau, Helsinki.

Thompson, J. L. (1995). Strategic Management Handbook, (CIMA Professional Book) Oxford: ButterworthHeinemann Ltd.

Tushman, M. L. \& Anderson, P. (1997). Managing Strategic Innovation and Change, New York: Oxford University Press.

Wagstyl, S. (2010). Business: a change in gear. Financial Times http://www.ft.com/cms/s/0/9edc55f25d2b-11df-8373-00144feab49a.html

Wheelen, T. L. \& Hunger, D. J. (1992). Strategic management and business policy (4th ed), USA: AdisonWesley Publishing Company, Inc.

Wood, D. (1991). Corporate Social Performance Revisited. The Academy of Management Review, 16(4), 691-717. 